\title{
Students' Ability in Developing Generic Structure, Cohesion and Coherence in Writing Hortatory Exposition Text
}

\author{
Yerny Syafnida $^{1 *}$ and Havid Ardi $^{2}$ \\ ${ }^{1 *}$ Universitas Negri Padang, Indonesia, Padang, $ه($ e-mail)yerni.syafnida82@gmail.com \\ ${ }^{2}$ Universitas Negri Padang, Indonesia, Padang, $\triangle$ (e-mail) havid_a@fbs.unp.ac.id
}

\begin{abstract}
Some English teachers always find several problems in teaching writing about the genre as the topics in the lesson plan. The problems are in the grammar, generic structure, cohesion and coherence. The purpose of this research is to describe how is the ability of students Grade XI social class of SMAN 8 Pekanbaru phenomenon in writing Hortatory Exposition text. The subjects of this research were the students at the grade XI social class registered in July-December 2019/2020 academic year. The data were collected through writing test on hortatory exposition text. It was found that the students' ability in building generic structure and cohesion was Adequate, and the students' ability in building coherence in hortatory exposition text was categorized as Good.
\end{abstract}

Keywords: Generic structure, cohesion, coherence, hortatory exposition text, writing

\section{INTRODUCTION}

The new curriculum in Indonesia, the 2013 curriculum, is one of the influences of genre-based approach as the trend today (Derewianka, 2003; Rose, 2006). This curriculum includes, syllabus and also lesson plan of teaching English in senior high school, one of the writing skills that should be master by the students is writing hortatory exposition text. This text is one kinds of text among of narrative, descriptive and also procedure. There are 3 parts of generic structure of hortatory exposition text. The first is Thesis that consists about introducing the writer's main idea about the topic of the text that will be discussed. The writer explains his position about that topic, as the proponent or the opposition in that writing text. The second is Arguments that consist of the writer's several arguments that support the main idea of the text. If the writer gives many arguments about that main idea it will make the hortatory exposition text become interesting. Because those arguments will make the readers believe about the writer's opinion. The last one is Recommendation that consist of the recommendation or persuasion of the writer to the readers about the topic that has been discussed in previous paragraph. However, several English teachers always find problems in teaching writing about the genre as the topics in the lesson plan.

The problems are in the grammar, generic structure, cohesion and coherence. Every text has different generic structure as the characteristics of the texts. The generic structure is an important part in building the texts. The problem from the teachers' complain of the students writing about the generic structure of the text is the students sometimes missing one or more part of the generic structure of the text. Although it has been explained in the teaching and learning process in the classroom, but the students still do that mistake.

In addition, there are some studies have been done on related reading genre based (Rose, 2006). Similarly, research on writing generic structure of the texts also attract many researchers. It is related to the way in which elements of a text are arranged to match its purpose. This structure can be observed by readers, and writers will use this knowledge to organize the structure their writing, depending on their purpose. This structuce has close relation with the genre and the researchers that have done the research in the generic stucture of the texts. For instance, Lusiana (2012) studied about the ability of students in writing procedure text, Yuniarti, Rahayu, Eripuddin (2015) discussed about generic structure in students' descriptive text. Besides, some researchers focus on their studies on recount text (Mingsakoon \& Srinon, 2018; Nurhidayat, 2011), anecdote recount text (Mingsakoon \& Srinon, 2019). Moreover, there are also researchers that explore newspaper, such the conjunction in opinion (Rira \& Ardi, 2013) and grammatical cohesion in children, adolescent, and adult's story (Sukriyah, Sumarlam, Djatmika, 2018). Therefore, there is a need of information on students' ability in writing hortatory essay.

Furthermore, cohesion and the coherence also take the important part in building a proper text. The cohesion and coherence talk about the writer's ideas of the text. The idea 
of the text should related and support each other. Like the sentence that have related to support the paragraph and the paragraph ideas that will support each other to build a text or essay. But to make the sentence or paragraph related each other is the problem by the students. According to the arguments and the previous research above, it is sure that to create a good writing in a text, generic structure are significant in writing a text. Both of them cannot be separated from the cohesion and also coherence because they are required in writing. From the explanation above, the researcher is interested to do the research about the generic structure, cohesion and also coherence of the students XI social class writing in building hortatory exposition text.

The hortatory exposition is a type of exposition texts which gives explanation or arguments for the fact. There several definitions and generic structures of hortatory exposition texts proposed by experts. According to Anderson \& Kathy (1997, p.83) hortatory exposition genre is a piece of text that present one side on an issues which has the purpose to persuade the reader and listener by presenting arguments, that is the case for or a case against. The texts deals with a problem overcome by giving some arguments to influence the readers. In general, the social function of hortatory exposition text is to persuade the people who read or listen to do or should not to do. In other words, hortatory and analytical exposition is different in the generic structures where analytical gives the conclusion and hortatory recommends the reader to do or not to do something (Gerot and Wignell, 1994, p. 209).

Furthermore, generic structure of Hortatory exposition mostly they are distributed into three components, they are: (1) Thesis, (2) Arguments and (3) Recommendation. Specifically, Gerot \& Wignell (1994, p. 210) in their book related to functional grammar state that generic structures, there are some lexico-grammatical features such as its focus on human and non-human participants, then use of mental, material and relational processes in the text and the use of simple present tense.

Feez \& Joyce (1998, p.56) explain that arguments in hortatory exposition text contain any factual information, evidence, description, or explanation which supports the thesis. Sometimes hortatory exposition begins with a background stage which provides any information the readers need in order to follow the arguments. They also add that the generic structures of this text are: a) a thesis or general statement that is introduces the issues and indicates the writer positions. b) series arguments which support the thesis, containing factual information, evidence, description, explanation which support the thesis. c) Recommendation is suggestion about the issues that are discussed

Furthermore, Saragih (in Hartati, 2014, p.23) clarifies the stage of this genre that consist of abstract, thesis, argument and recommendation. Abstract stage means to give brief definition of the case under discussion. After that, the thesis stage proposes the idea, opinion, proposal, as well as side, namely protagonist or antagonist. The next, the arguments stages contains some examples, illustration, statistics or quotations are given to support the thesis statement. And the last is conclusion which gives confirmation on the thesis by paraphrasing, summarizing or giving implication.

Beside the generic structure, the characteristics of good writing are related to the cohesive and coherence devices. Both of them are the most important part in the process of good writing beside grammar in the sentences or paragraphs. There are many researchers that have discussed about the concepts of cohesion and coherence in texts and discourse studies. Most of them have the same point of view that cohesion is different from coherence. To see how cohesion and coherence difference one another, the explanations of both concepts are explained below.

Specifically, some experts also differentiate the term cohesion and coherence, such as, the term cohesion is used to explain the structure inside the text. Meanwhile, the term coherence is used to explain the concepts and the relations underlying its meaning (Louwerse \& Graesser; 2005 , p. 103). On the other hand, coherence is the outcome of a dialogue that appears between the text and its listener or reader. It is in line with Zemach \& Rumisek that explain coherence as a clear and logical way of the sequence of ideas in a text or essay (Zemach \& Rumisek, 2005, p. 82). This coherence will help the reader in understanding the text whenever a text is built as a unity. Therefore, the people can comprehend the main idea and thesis in text written by the author easily. Thus, coherence can be said as the paragraph that is easy to read and understand by the readers as the sequence of supporting sentences are arranged in acceptable logical order and the ideas are presented and linked each other by suitable transition signal.

Moreover, related to the definition of cohesion, some experts state that cohesion is defined as the phrases linked each other to build the whole connection in the text to be able to be read and clear as the discourse itself (Bailey, 2003, p.55; Renkema, 2004, p.103-106). For instance, the sentence "Mary got pregnant and she married" according Renkeme is an example of a sentence that have good cohesion. Mary is replaced with the word "she". It means, "she" refers to Mary.

To achieve the cohesion, a writer can do some process. Firstly, it can be done using conjunction and the link of phrases and sentences with words like he, they, and that which refer back to something mentioned before (Bailey, 2003, p.55). For example, "Jane Austen wrote six major novels in her short life. She deal with domestic drama in middle-class families." In the sentence above, the word her refers to the author. Then, Jane Austen, and the word they refer to the six major novels that she wrote during her life. Therefore, there is a clear connection between the whole text shown by the word "her" and "them".

Since the generic structure, cohesion and also coherence are very important in building texts. The research about the analyzing the students' ability in writing hortatory exposition text of XI social class of SMAN 8 Pekanbaru is important to be done. By conducting this research, it is expected to know the students mastery and also their problems in writing the generic structure of hortatory exposition texts. 


\section{METHOD}

The method used in this research was descriptive qualitative design. The subjects of this research were the students XI social class of SMAN 8 Pekanbaru. The student XI social class populations were 1, 2 and 3 that have been registered in July-December 2019/2020academic year. The instrument of this research was a writing test in order to get the data of the students' writing of generic structure in the hortatory exposition text. In this research, the test has been given to the students to write hortatory exposition texts. The writer applied some procedures to collect the data through the writing test. Firstly, the students are given some topics to be chosen before writing activity. In addition, the reason for giving the test once and suddenly was to make the test real the idea from the students' knowledge after getting the lesson about the topic Hortatory Exposition Text. The scoring rubrics used to analyze the data related to students' generic structures, cohesion, and coherences were adapted from Hamp-Lyon. The categories of students' writing are based the criteria 1-5 given (See Hamp \& Lyon, 1992, p. 6-7).

\section{RESULTS AND DISCUSSION}

There are five main topics provided by the researcher related to the hortatory exposition texts. They are: Are Smartphone really dangerous? Is fashion really important in teenagers? Is it useful to have relationship among of teens? Do social media give impact to the students' life? Should homework stop in school? According to the data, it was found that from 36 texts, 11 students choose the topic Are smartphones really dangerous? 2 students write about is fashion really important in teenagers? 1 student likes the topic, is it useful to have relationship among of teens? 5 students write about do social media give impact to the students' life? The most favorite topic in this writing test is Should Homework Stop in School? This topic is chosen by 12 students.

The percentage of students chose the first topic were $25.9 \%$ or about 14 students, after that the second topic was $3.7 \%$ or about 2 students. The third $1,8 \%$ topic only chose by a student and the forth topic is $12.9 \%$ or chosen by the 7 students. The last topic is the most favorite topic. It is chosen by 26 students or $48.1 \%$. In choosing the topics, they were 6 students' hortatory exposition text failed. They were caused because the students only gave the question for every topic.

Based on the data collected from students' writing, the first finding is about the students' ability in building generic structure into hortatory exposition text written by XI Social Class students of SMAN 8 Pekanbaru. The students' ability on this part is Adequate. Where the score shows after the final score of thesis statement plus the final score of the argument and also plus the final score of the then divided by 3 is 2.79 . It means that they have low understanding on generic structure.

The second finding about the ability of the students in developing cohesion in students' hortatory exposition text. After scoring students' writing the final score of the use of reference, substitution, conjunction, ellipsis, and including lexical cohesion in their writing, the final score of the students' ability can be concluded as adequate. It shows by the result of the score of all students is 2.39 which indicates that the students still have low understanding in using cohesive devices in their writing text.

Then, the third is related to students' ability in developing coherence in their hortatory exposition text. In this part after analyzing and accounting the score of the students' writing in the part of repetition of the key noun, pronoun, time signal and also the logical order, the students' ability is Good. It shows by the result of the final score of all students is 3.60 which indicates that the students are good in understanding on coherence devices.

There were three indicators of generic structure which were analyzed they were thesis statement, arguments and also conclusion. After that five indicators of cohesion devices which were analyzed in students' essay, for instance, the use of ellipsis in the text, including substitution, reference, conjunction, and lexical cohesion and there were four indicators which indicated cohesion devices such as the repetitions of key word/noun. Then, the researcher also analyzed the use of pronoun in their text, the use of transition signals, and the logical orders developed in the text. Then, the results of the research were supported by the analysis of each indicator of generic structure, cohesion and coherence devices in hortatory exposition text.

The result of this study were in line with some researchers' findings such as Mubarak, Hamzah, \& Radjab (2013) which stated that problems found in argumentative writing text was similar. In addition, the problems found in argumentative writing were quite similar to the previous research findings. The researcher found that only few students who were good at writing argumentative essays in developing good cohesion and coherence through some devices in their texts. Then, it was found that there some of them that were worse than those who were in high average criteria. It indicates that the students still have problems related to cohesion and coherence. Similarly.

The implication of this research is in relation to the findings of the research that the Generic Structure, Cohesion and Coherence devices need to be introduced completely to the students of SMAN 8 Pekanbaru since they have to improve their writing ability especially in writing text. The generic structure will always be found in many kinds of genre of texts. It will have different criteria in every text. On the other hands, the cohesion and coherence devices are helpful materials to be developed in teaching writing at schools because these will very important to the students ability in mastery of writing latter. Both cohesion and also coherence as the unity of the text and also have function to help the readers understand what the writer mea ns, should also be introduced to the student. In this part, will make the reader assume that the writer have a good idea or not. This study is limited to the students $\backslash$ generic structure, cohesion and coherence in hortatory exposition. The 
further research on analyzing the students' generic structure, cohesion, and coherence in other genres of texts need to be conducted.

\section{CONCLUSIONS}

Based on the analysis of each indicator of generic structure, cohesion and coherence devices from students' hortatory exposition text, it was found that the 11 Social Class of students' SMAN 8 Pekanbaru ability in building generic structure was adequate. After that, cohesion through some devices into Hortatory Exposition text was adequate too. Then, in the same way, it was also found the students' ability in building coherence through some devices into hortatory exposition text was good.

\section{ACKNOWLEDGMENTS}

I would like to offer heartiest gratitude to all those who support me in conducting this research. Firstly, I would like to say Alhamdulillah all praise to Allah SWT, for giving me strength and encouragement during all the moments in completing this research. Secondly, I would like to appreciate my great appreciation to the head master of SMAN 8 Pekanbaru who allowed me to conduct this research and students of grade XI social science of SMAN 8 Pekanbaru who participated in this research.

\section{REFERENCES}

[1] Derewianka B. (2003). Trends and issues in genrebased approach. A Journal of Language Teaching and Research. 34(2): 133-149.

[2] Rose D. (2006). Reading genre: A new wave of analysis. Linguistics and Human Science. 2(1): 24-49.

[3] Lusiana. (2012). A study on the students; ability in writing procedure text (A descriptive study on the seventh grade students of SMP Bina Utama Pontianak in academic year 2011/2012. (Unpublished Thesis). Pontianak: FKIP Universitas Tanjung Pura.

[4] Yuniarti, Y., Rahayu, P., Eripuddin. (2015). Analysis of generic structure in writing descriptive text at the ninth grade students of SMPN 3 Rambah Hilir. Ejournal mahasiswa Prodi Bahasa Inggris FKIP Pasir Pangaraian. 1(1)

[5] Mingsakoon, P. \& Srinon, U. (2018). Development of secondary school students' generic structure execution in personal experience recount writing text through SFL genre-based approach. Advances in Language Literary Studies. 9(6), 1-8.

[6] Nurhidayat, T. (2011). Students' ability in writing recount based on generic structure, language features and social function (A case of the tenth grade students of State Senior High School 2 Pemalang in the first semester of academic year 2010/2011). Semarang: Universitas Negeri Semarang.

[7] Mingsakoon, P. \& Srinon, U. (2019). Generic structure development on upper secondary school students' personal anecdote recount writing text through SFL (systemic functional linguistics) genre- based approach. Rajabhat Journal of Sciences, Humanities \& Social Sciences. 20(1), 111-122.

[8] Rira, F. \& Ardi, H. (2013). The conjunction used in opinion column of Singgalang newspaper. E-journal of English Language and Literature, 2(1).

[9] Sukriyah, S., Sumarlam., Djatmika. (2018). Grammatical cohesion of personal pronouns in children's stories, adolescent stories, and adult stories of Kompas. Lingua Didaktika: Jurnal Bahasa dan Pembelajaran Bahasa. 12(1), 59-75.

[10] Anderson, M \& Kathy A. (1997). Text Types in English. South Yarra: MacMillan

[11] Gerot, L. \& Wignell, P. (1994). Making Sense of Functional Grammar. Sydney: Antipodean Educational Enterprise.

[12] Feez, S \& Joyce, H. (1998). Writing Skill Narrative and Non-Fiction Text Types. Melbourne: Phoenix Education

[13] Bailey, S. (2003). Academic Writing: A Practical Guide for Students. New York: Routledge.

[14] Hamp-Lyons, L. (1992). Holistic writing assessment for LEP students, in Office of Bilingual Education and Minority Languages Affairs (ed.), Proceedings of the Second National Research Symposium on Limited English Proficient Student Issues: Focus on Evaluation and Measurement, Volume 2. Washington, DC: OBEMLA. 317-358.

[15] Hartati, H. (2014). The Effect of Direct Reading Thinking Activity (DRTA) Strategy and Students' Reading Motivation toward Their Reading Comprehension in Hortatory Hortatory exposition Text at the Eleventh Grade of SMA Negeri 1 Merangin. Padang: State University of Padang (Unpublished Thesis)

[16] Louwerse, M.M. \& Graesser, A.C. (2005). Coherence in Discourse. In Strazny, P. (ed), Encyclopedia of Linguistics. Chicago: Fitzroy Dearborn.

[17] Mubarak, Z.H., Hamzah, Radjab, D. (2013). An analysis of students' ability in building cohesion and coherence in argumentative essays written by the fourth year students of English Department at Univerity of Bengkulu. Journal of English Language Teaching. 1(3), 23-35.

[18] Renkema, J. (2004). Introduction to Discourse Studies. Amsterdam: John Benjamins Publishing Company.

[19] Zemach, D. E. \& Lisa, A. Rumisek. (2005). Academic Writing: From Paragraph to Essay. Oxford: Macmillan Publisher Limited.

[20] Zainuddin. Z. (2016). Syntax errors on the essay writings of extrovert and introvert EFL learners. Lingua Didaktika: Jurnal Bahasa dan Pembelajaran Bahasa. 10(1), 95-104. 